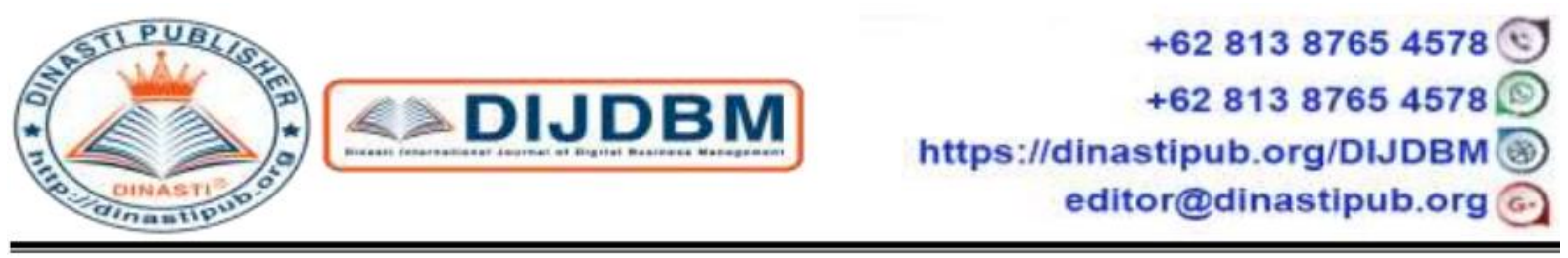

\title{
THE EFFECT OF ALTMAN Z - SCORE FINANCIAL RATIO ON STOCK PRICE (STUDY ON GO PUBLIC PLANTATION SUBSECTOR COMPANIES IN INDONESIA STOCK EXCHANGE)
}

\author{
Muhammad Fachri Radityatama'), Matrodji H. Mustafa ${ }^{2)}$ \\ 1,2) Master of Management, University of Mercubuana, Jakarta, Indonesia
}

\begin{tabular}{|c|c|}
\hline $\begin{array}{l}\text { ARTICLE INFORMATION } \\
\text { Received: } 26 \text { December } 2019 \\
\text { Revised: 31 December } 2019 \\
\text { Issued: } 7 \text { January } 2020 \\
\\
\text { Corresponding author: } \\
\text { Muhammad Fachri Radityatama } \\
\text { E-mail: } \\
\text { fachritama758@gmail.com, } \\
\text { mustafamatt@yahoo.com }\end{array}$ & $\begin{array}{l}\text { Abstract: This study aims to examine and analyze the effect } \\
\text { of the ratio - financial ratios Altman Z-Score on stock prices } \\
\text { (study at the plantation subsector company that went public on } \\
\text { the stock exchanges of Indonesia). The research data is annual } \\
\text { data from } 2014 \text { until } 2018 \text {. The sampling method used was } \\
\text { purposive sampling. Of the population of } 16 \text { companies in the } \\
\text { plantation subsector, } 15 \text { companies met the criteria plantation } \\
\text { sub-sector into the sample. The analytical method used in this } \\
\text { study is panel data regression. The results showed Working } \\
\text { Capital to Total Assets (WCTA), Retained Earnings to Total } \\
\text { Assets (RETA), Earnings Before Interest and Tax (EBITTA) } \\
\text { and Market Value Equity to Book Value of Total Liabilites } \\
\text { (MVEBTL) together - the same (simultaneous) effect } \\
\text { significant positive stock price } \\
\text { Keywords: Working Capital to Total Assets (WCTA), } \\
\text { Retained Earnings to Total Assets (RETA), Earnings Before } \\
\text { Interest and Tax (EBITTA), Equity Market Value to Book } \\
\text { Value of Total Liabilites (MVEBTL) Stock Price }\end{array}$ \\
\hline
\end{tabular}

\section{INTRODUCTION}

Indonesia is an agricultural country, where most people are farmers not only that, even the Indonesian plantation crops can carry the Indonesian economy. It was submitted also by Nurmayanti (2017) which states that plantations provide a very important role for the economic fundamentals of Indonesia and written by statements from Machmud (2017) which states that plantations play an important role as a driver of prosperity and development of remote wilaya. Not only that, the estate is also a source of gluten nation for closer community members who live in areas far from urban and rural areas.

Plantation subsector is one sub-sector of the agricultural sector to increase foreign exchange and create employment (Rachmat, 2017). Government emphasis on plantation subsector, because it has a high appeal for export to developed countries. Commodities including estate crops include oil palm, coconut, rubber, coffee and tea. When viewed from the value of its stock price index, the plantation subsector decreased from 2017 until 2018.

Index of stock prices in 2017 up to 2018 in the plantation sub-sector are as follows: 
Table 1. Composite Stock Price Index Sub Sector contained in the Indonesia Stock Exchange Year 2017 up to 2018

\begin{tabular}{lrr}
\hline \multicolumn{1}{c}{ subsectors } & \multicolumn{2}{c}{ Year } \\
\cline { 2 - 3 } & 2017 & 2018 \\
\hline \hline Plantation & $-13 \%$ & $-3 \%$ \\
Mining & $15 \%$ & $11 \%$ \\
Basic and Chemical Industry & $28 \%$ & $24 \%$ \\
various Industries & $1 \%$ & $1 \%$ \\
Industrui Consumer Goods & $23 \%$ & $-10 \%$ \\
Property, Real Estate and Building & & \\
Construction & $-4 \%$ & $-10 \%$ \\
Infrastructure, Utilities and Transportation & $12 \%$ & $-10 \%$ \\
finance & $41 \%$ & $3 \%$ \\
Trade, Services and Investment & $7 \%$ & $-15 \%$ \\
\hline \hline
\end{tabular}

Plantation sub-sector in recent years, especially in 2017 up to 2018 experienced a sharp decline of the number of percentage compared to other sub-sectors. Andry (2018) states that it can be caused by impairment export of products promoted plantation Indonesia throughout 2018. The economy is not stable causing high risk of a company experiencing financial difficulties or even bankruptcy. If a company does not immediately address the short-term financial difficulties (liquidity) that happened, it will lead to long-term financial difficulties (solvency) which can lead to bankruptcy of the company.

Hence the importance of this study is expected to be a picture and can provide input and analysis to investors interested to invest in plantation sub-sector, but it can help investors assess based on the fundamentals of the company, which companies are eligible or not to do their investment, so what investors are expected to be achieved.

Based on the above, it is necessary to study the condition of the company plantation sub-sector listed in Indonesia Stock Exchange (BEI) in the period 2015 until 2018 with menggutakan ratios Altman Z - Score which is proxied by the Working Capital to Total Assets (WCTA), Retained Earnings to Total Assets (RETA), Earnings Before Interest and Tax (EBITTA) and Market Value Equity to Book Value of Total Liabilites (MVEBTL).

\section{LITERATURE REVIEW}

Several previous studies related to this study has been carried out by some previous researchers such as: Yuniarti (2014), Sukmawati, et al (2014), Handojo (2001), Noviarti (2017), Mario (2012), Marcelina, et al (2014 ), Ramadan (2018), Jurnaidah, et al (2018).

The share price is the price is formed due to the influence of supply and demand in the market stock exchange by market participants (Jogiyanto, 2010). If a stock is oversubscribed, then the stock price tends to rise. Conversely, if excess supply then stock prices tend to fall.

Signaling Theory was first coined by Michael Spence (1973) in his research entitled JobMarket Signaling. This theory involves two parties: the party in such management is an important signaling and external parties such as investors who acts as the party receiving the signals. The management strives to provide relevant information that can be utilized by the investor. Then, the investor will adjust its decision in accordance with its understanding of the 
signals. This theory was developed back by Ross (1977), explained that the company executives who have better information about the company will be compelled to provide this information to investors. By because it, the information will affect the volume of stock trading.

Information asymmetry occurs when one party of a transaction discount more information than the other party. Generally, the seller who has more product information than the buyer, even though the opposite may also be in question. This condition was firstdescribed by Kenneth J. Arrow in a famous article in the field of health care in 1963 entitled "Uncertainty and the Welfare Economics of Medical Care," in the journal American Economic Review. While the term Asymmetric information is used by George Akerlof in his 1970: The Market for Lemons (Kacangan Goods Market). According to George (1970) states that, in such a market, the average value of a commodity tends to go down, even for goods that are classified as good quality. Sellers who do not intend either going to cheat buyers by giving the impression that the goods that it sells good, this case raises the Adverse Selection. Adverse Selection is how the selection decision will be taken based on the information that is weak. This can lead to moral hazard.moral hazarda deliberate action taken so that the objective can be achieved. For example, to hide things - important things as information for the company.

Fama (2010) gives the sense that the concept of efficient markets means that the current stock price reflects all available information. This means that the good information from the information of past, present and supplemented by information from persusahaan itself (insider information).

Bankruptcy is a condition in which the company no longer able to repay its obligations (Prihadi, 2010: 33). Meanwhile, according Fakhrurozie (2007: 15) states that bankruptcy can be defined as a failure in the sense that the failure of the economic and financial failures.

The ratio of Working Capital to Total Assets (WCTA) is the ratio of working capital to total assets, is often found in the case study company's problems, this is the size of the net on the company's current assets to capital companies. Net working capital is the difference between current assets less current liabilities.Liquidity characteristics really clearly defined usually a company that rnengalami continuous operating losses will shrink the current assets in relation to total assets. Among the assessment of the liquidity ratio, it proved most valuable (Altman, 1968: 594-595). Here is the formula of the ratioWorking Capital to Total Assets (WCTA):

$$
\text { WCTA }=\frac{\text { Working Capital }}{\text { Total Assets }}
$$

Retained Earnings Ratio to Total Assets (RETA) is a measure of cumulative profitability over time is mentioned in the beginning as one of the new ratio. Age company implicitly expressed in this ratio, a relatively new company may show the ratio of retained earnings / total assets were lower due to lack of time to add a cumulative profit (Altman, 1968: 595). Meanwhile, according Endri (2009: 42) RETA is a ratio showingthe company's ability to generate retained earnings of the total assets of the company. Here is the formula of the ratioRetained Earnings to Total Assets (RETA):

$$
\text { RETA }=\frac{\text { Retained Earning }}{\text { Total Assets }}
$$

ratios Earnings Before Interest and Tax to Total Assets(EBITTA) is the ratio used to measure the actual productivity of the assets of the company (Kamaludin, 2011: 57). Meanwhile, according to Altman (1968: 595) This ratio is calculated by dividing the total assets of the 
company with earnings before interest and tax deductions divided by total assets.Here is the formula of the ratio Earnings Before Interest and Tax to Total Assets(EBITTA):

$$
\text { EBITTA }=\frac{\text { EBIT }}{\text { Total Assets }}
$$

ratios Equity Market Value to Book Value of Total Liabilites(MVEBTL) is the ratio of the book value of equity with a total book value of the debt. This ratio is used to detect the amount of the company's equity from the total liabilities of the company (Kurniawan, 2018). In general, companies disclose the changes - changes in the rights - the rights of the shareholders in a separate report in the form of reports the change in equity. The book value of equity (Book Value of Equity) was calculated based on the book value of assets less the book value of liabilities. While the book value of debt is calculated based on short-term liabilities plus longterm liabilities. Here is the formula of the ratio Equity Market Value to Book Value of Total Liabilites (MVEBTL):

$$
\text { MVEBTL }=\frac{M V E}{B T L}
$$

Based on the above literature review, theoretical framework of the study are as follows:

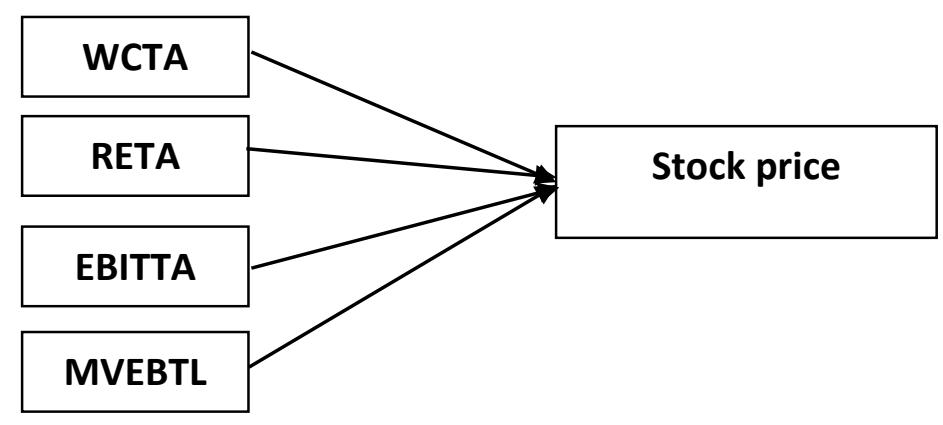

Figure 1. Theoretical Framework

\section{RESEARCH METHODS}

This study is to determine the effect of the ratio casual WCTA, RETA, EBITTA, and MVEBTL on stock prices. Data used in the company's financial data from plantation sub-sector in the period from 2014 until 2018. The samples collected consist of 15 (fifteen) companies. Methods of data analysis used in this study is panel data regression analysis method. Panel data regression analysis was used to determine the influence of the independent variable on the dependent variable. Panel data regression equation as follows:

Yit $=\alpha+\beta$ Xit $+\varepsilon i t$

Where:

YIT = Variable observation unit in response to $\mathrm{i}$ and time to $\mathrm{t}$

Xit $=$ The predictor variables in the observation unit to $\mathrm{i}$ and time to $\mathrm{t}$ 
$\alpha \quad=$ Intercept regression model

$\beta=$ Coefficient of inclination or direction coefficient

eit $=$ Error component in the observation unit to $\mathrm{i}$ and time to $\mathrm{t}$

Then, the simultaneous test ( $\mathrm{F}$ - statistics) do.The statistical test $\mathrm{F}$ basically indicates whether all the independent variables or free inclusion in the model have influence together against vaiabel dependent / bound, If the model is significant, then we'll see the results of the coefficient of determination. Coefficient of determination is used to determine the relationship between the dependent variable and independent variables. The greater the value of $\mathrm{R} 2$, the more precise regression models were used as a tool for forecasting. If the value of R2 are small means the ability of independent variables in explaining the variation is very limited dependent variables. The t-test statistics basically show how far the influence of the independent variable on the dependent variable partially entered into the model. According to the Way (2018) $t$ test was used to test individual regression coefficient.

\section{FINDINGS AND DISCUSSION}

Table 2. Common Effect Model

Dependent Variable: HGSHM

Method: Pooled Least Squares

Date: 08/02/19 Time: 14:29

Sample: 15

Included observations: 5

Cross-sections included: 15

Total pool (balanced) observations: 75

\begin{tabular}{crcrr}
\hline \multicolumn{1}{c}{ variable } & coefficient & Std. Error & t-Statistic & Prob. \\
\hline C & 1508.634 & 91.73922 & 16.44481 & 0.0000 \\
WCTA & 21.30741 & 228.6590 & 0.093184 & 0.9260 \\
RETA & -199.0498 & 201.9068 & -0.985850 & 0.3276 \\
MVEBTL & 321.2083 & 116.0554 & 2.767716 & 0.0072 \\
EBITTA & 1756.537 & 764.6331 & 2.297229 & 0.0246 \\
\hline \hline & 0.173406 & Mean dependent var & & 1836.233 \\
R-squared & 0.126172 & SD dependent var & & 281.7374 \\
Adjusted R-squared & 263.3646 & Akaike information criterion & 14.04930 \\
SE of regression & 4855265 . & Schwarz criterion & & 14.20380 \\
Sum squared resid & -521.8486 & Hannan-Quinn criter. & & 14.11099 \\
Log likelihood & 3.671215 & Durbin-Watson stat & & 1.268401 \\
F-statistic & 0.009007 & & \\
Prob (F-statistic) & & & \\
\hline \hline
\end{tabular}

This common effect on the model assumes that each individual unit has the same intercept and slope (there is no difference in a close time dimension). In other words, the panel data regression data produced will apply to each individual (Juanda and Juanidi, 2012: 180). Based 
on table 2 it can be concluded that the regression models based on those common effect MVEBTL ratios yield significant results is less than 0.05 , which means a positive effect on stock prices, while the ratio of WCTA, RETA, and EBITTA, has a value of more than 0.05, which means that the ratio the tdak effect on stock prices at the plantation sub-sector companies listed on the Indonesia stock Exchange period from 2014 until 2018.

\section{Table 3. Fixed Effect Model}

Dependent Variable: HGSHM

Method: Pooled Least Squares

Date: 08/02/19 Time: 14:30

Sample: 15

Included observations: 5

Cross-sections included: 15

Total pool (balanced) observations: 75

\begin{tabular}{crrrr}
\hline \hline variable & coefficient & Std. Error & t-Statistic & Prob. \\
\hline \hline C & 184.0335 & 77.38142 & 2.378265 & 0.0208 \\
WCTA & 18.75181 & 147.8402 & 0.126838 & 0.8995 \\
RETA & 263.4505 & 161.7676 & 1.628573 & 0.1090 \\
MVEBTL & 1207.808 & 193.2858 & 6.248819 & 0.0000 \\
EBITTA & 9440.296 & 1518.014 & 6.218848 & 0.0000 \\
Fixed Effects & & & & \\
(Cross) & & & & \\
_AALI - C & -1626.647 & & & \\
_ANJT - C & -706.0419 & & & \\
_BWPT - C & 799.6863 & & & \\
_DSNG - C & 43.15752 & & & \\
_GZCO - C & 702.8818 & & & \\
_JAWA - C & 586.6560 & & & \\
_LSIP - C & -449.3834 & & & \\
_PALM - C & -135.3192 & & & \\
_SGRO - C & -359.8798 & & & \\
_SMAR - C & 247.3920 & & & \\
_SIMP - C & 249.5443 & & & \\
_TBLA - C & 482.3605 & & & \\
_SSMS - C & -127.3433 & & & \\
_MAGP - C & -65.96577 & & & \\
_UNSP - C & 358.9023 & & & \\
\hline \hline
\end{tabular}

Effects Specification

Cross-section fixed (dummy variables)

\begin{tabular}{llll}
\hline \hline R-squared & 0.894906 & Mean dependent var & 1836.233 \\
Adjusted R-squared & 0.861126 & $\begin{array}{l}\text { SD dependent var } \\
\text { Akaike information }\end{array}$ & 281.7374 \\
SE of regression & 104.9916 & criterion & 12.36017 \\
Sum squared resid & 617300.9 & Schwarz criterion & 12.94726
\end{tabular}




\begin{tabular}{lrll} 
Log likelihood & -444.5063 Hannan-Quinn criter. & 12.59459 \\
F-statistic & 26.49214 Durbin-Watson stat & 1.735440 \\
Prob (F-statistic) & 0.000000 & \\
\hline \hline
\end{tabular}

Fixed Effect on the model of the intercept in the regression can be distinguished between individuals because each individual is considered to have its own characteristics. In the intercept can be used to distinguish the dummy changer, so this method is known as the Least Squares Dummy models Variabels (Juanda and Junaidi, 2012: 180). Based on Table 3 it can be concluded that based on the ratio of fixed effect regression models MVEBTL and EBITTA produce significant results is less than 0.05 , which means a positive effect on stock prices and RETA WCTA while the ratio has a value greater than 0.05 , which means that the ratio it does not affect the company's share price at the plantation sub-sector listed in Indonesia stock Exchange period 2014 to 2018.

Table 4. Random Effect Model

Dependent Variable: HGSHM

Method: Pooled EGLS (Cross-section random effects)

Date: 08/02/19 Time: 14:32

Sample: 15

Included observations: 5

Cross-sections included: 15

Total pool (balanced) observations: 75

Swamy and Arora estimator of component variances

\begin{tabular}{|c|c|c|c|c|}
\hline variable & coefficient & Std. Error & t-Statistic & Prob. \\
\hline $\mathrm{C}$ & 1508.634 & 36.57228 & 41.25076 & 0.0000 \\
\hline WCTA & 21.30741 & 91.15600 & 0.233747 & 0.8159 \\
\hline RETA & -199.0498 & 80.49110 & -2.472942 & 0.0158 \\
\hline MVEBTL & 321.2083 & 46.26603 & 6.942637 & 0.0000 \\
\hline EBITTA & 1756.537 & 304.8246 & 5.762452 & 0.0000 \\
\hline $\begin{array}{c}\text { Random Effect } \\
\text { (Cross) }\end{array}$ & & & & \\
\hline _AALI - C & 0.000000 & & & \\
\hline ANJT - C & 0.000000 & & & \\
\hline _BWPT - C & 0.000000 & & & \\
\hline DSNG - C & 0.000000 & & & \\
\hline GZCO - C & 0.000000 & & & \\
\hline JAWA - C & 0.000000 & & & \\
\hline _LSIP - C & 0.000000 & & & \\
\hline _PALM - C & 0.000000 & & & \\
\hline _SGRO - C & 0.000000 & & & \\
\hline _SMAR - C & 0.000000 & & & \\
\hline _SIMP - C & 0.000000 & & & \\
\hline _TBLA - C & 0.000000 & & & \\
\hline _SSMS - C & 0.000000 & & & \\
\hline
\end{tabular}




$\begin{array}{ll}\text { _MAGP - C } & 0.000000 \\ \text { _UNSP - C } & 0.000000\end{array}$

Effects Specification

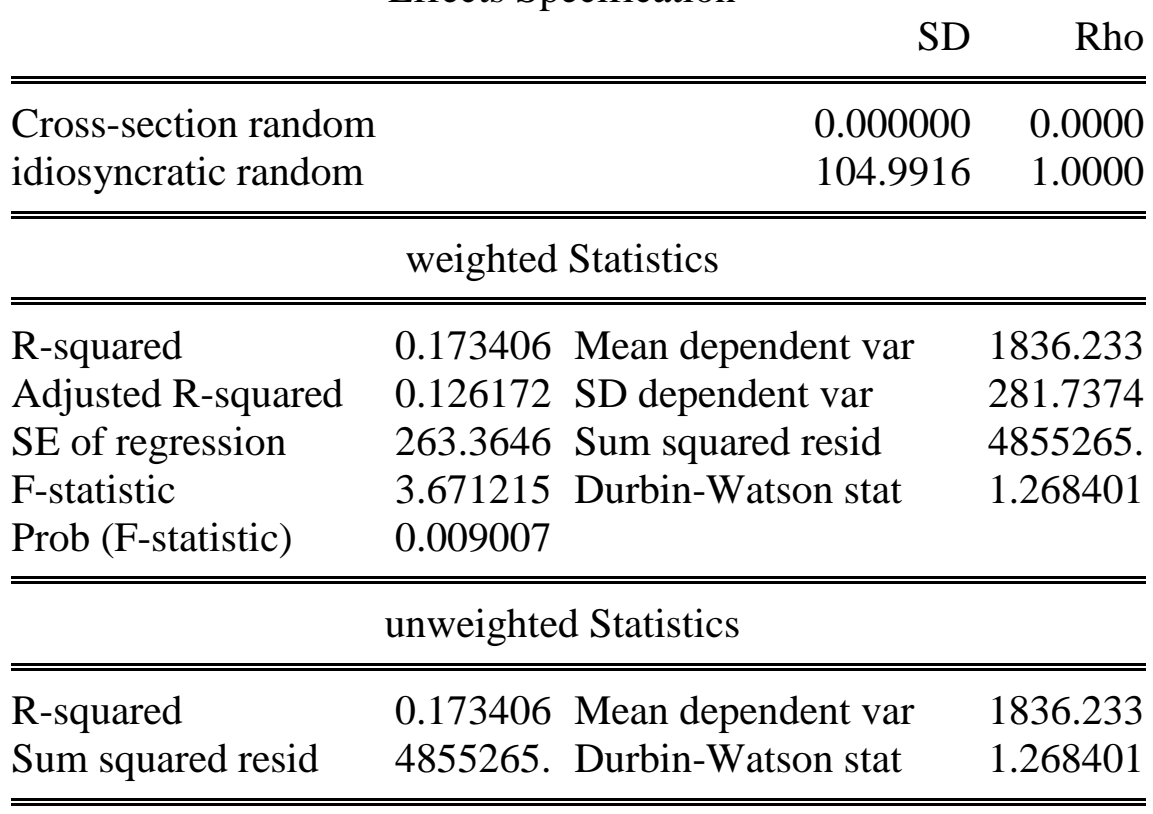

Random Effect Model on individual characteristics and the time differences are accommodated on the errors of the model. Considering there are two components that have contributed to the formation of error, the individual and time, random error on the Random Effect Model also needs to be broken down into error for the individual components, error time and error components combined. The random method is also known as Error Components Model (ECM) (Juanda and Junaidi, 2012: 182). Based on Table 4 it can be concluded that based on the regression model of Random Effect Model RETA ratio, MVEBTL, and EBITTA produce significant results is less than 0.05 , which means a positive effect on stock prices, while the WCTA ratio has a value greater than 0.05 means that the ratio does not affect the company's share price at the plantation sub-sector listed in Indonesia stock Exchange period from 2014 until 2018.

\section{Table 5. Test Chow}

Redundant Fixed Effects Tests

Pool: Untitled

Test cross-section fixed effects

\begin{tabular}{lrrr}
\hline \hline Effects Test & statistics & df & Prob. \\
\hline \hline Cross-section F & 27.461256 & $(14.56)$ & 0.0000 \\
Cross-section Chi-square & 154.684686 & 14 & 0.0000 \\
\hline \hline
\end{tabular}

Chow test that is testing to determine the model Common Fixed Effect Effect or right that Palin used in estimating panel data. Based on Table 5 that the test results and Fixed Effect Common 
Fffect obtained probability value is less than 5\% alpha (0.0000>0.05). So H0 is rejected Ha accepted which means plaing right model is the Fixed Effects Model.

Panel data model of linear regression equation in this study as follows:

$$
Y=184.0335+263.450518 .75181 X 1+X 2+X 3+9440.2961207 .808 X 4
$$

\section{Table 6. Test Hausman}

F-Statistic 26.49214

Prob (F-Statistics) $\quad 0.000000$

Hausman test that is testing to determine the model Fixed Effect Random Effect Model or the most appropriate model in estimating panel data. Based on table 6 that the test results Fixed Effect Random Effect Model or models obtained probability value is less than $5 \%$ alpha $(0.0000>0.05)$. so $\mathrm{H} 0$ is rejected Ha accepted which means the most appropriate model is the Fixed Effects Model.

\section{Table 7. Test Model F}

\begin{tabular}{ll}
\hline F-Statistic & 26.49214 \\
Prob (F-Statistics) & 0.000000 \\
\hline
\end{tabular}

Based on Table 7, it can be seen that the F - Statistics $=26.49214>3: 11$ (Ftabel) and has a probability value of $\mathrm{F}$ - Statistics of $0.000000>0.05$. So that the models used are not eligible to explain the influence of the independent variable on the dependent variable.

Table 8. The coefficient of determination (R2)

\begin{tabular}{ll}
\hline R-Squared & 0.894906 \\
Adjusted R-Squared & 0.861126 \\
\hline
\end{tabular}

Based on the results of such calculations in Table 8 above it can be seen that the influence of the independent variable on the dependent variable stock price visible plantation sub-sector of Adjusted R-Squared value that is equal to 0.861126 , or $86.1126 \%$. it indicates $86.1126 \%$ of the share price can be explained by the variation of all independent variables are Working Capital to Total Assets (WCTA), Retained Earnings to Total Assets (RETA), Earnings Before Interest and Tax to Total Assets (EBITTA), Market Value of Book Equity to Book Value of Total Liability (MVEBTL). While the rest of $100 \%-86.1126 \%=13.8874 \%$ explained by other independent variables were not examined. 
Table 9. Test t

\begin{tabular}{ccccc}
\hline \hline variable & coefficient & Std. Error & t-Statistic & Prob. \\
\hline \hline C & 184.0335 & 77.38142 & 2.378265 & 0.0208 \\
WCTA & 18.75181 & 147.8402 & 0.126838 & 0.8995 \\
RETA & 263.4505 & 161.7676 & 1.628573 & 0.1090 \\
MVEBTL & 1207.808 & 193.2858 & 6.248819 & 0.0000 \\
EBITTA & 9440.296 & 1518.014 & 6.218848 & 0.0000 \\
\hline
\end{tabular}

From the results of model estimation, hypothesis testing was done in accordance with the purpose of research. T test conducted to determine the effect of the ratio WCTA, RETA, MVEBTL, EBITTA of the company's stock price partially plantation sub-sector (itself). The ttest performed by the decision when the value prob. $\mathrm{t}$ - statistic <of the level of significance (0:05), then the independent variables have a significant influence on the dependent variable, and vice versa.

\section{CONCLUSION AND SUGGESTION}

The results of hypothesis testing as follows:

\section{hypothesis 1}

H0: Working Capital to Total Assets (WCTA) had no effect on stock prices.

Ha: Working Capital to Total Assets (WCTA) has a positive effect on stock prices.

Based on table 9, test variables Working Capital to Total Assets (WCTA) on stock prices of companies in the plantation subsector that listed in Indonesia Stock Exchange (BEI) in the period from 2014 until 2018 resulted in a probability value of 0.8995 is greater than the level of significance is 0:05, this indicates that the variable Working Capital to Total Assets (WCTA) did not significantly influence the company's stock price in the plantation subsector that listed in Indonesia stock Exchange (BEI) in the period from 2014 until 2018. Then the hypothesis H0 stating Working Capital to Total Assets (WCTA) does not affect the company's stock price in the plantation subsector that listed in Indonesia stock Exchange period from 2014 until 2018.

\section{hypothesis 2}

H0: Retained Earnings to Total Assets (RETA) has no effect on stock prices.

Ha: Retained Earnings to Total Assets (RETA) has a positive effect on stock prices.

Based on table 9, test variables Retained Earnings to Total Assets (RETA) on stock prices of companies in the plantation subsector that listed in Indonesia Stock Exchange (BEI) in the period from 2014 until 2018 resulted in a probability value of 0.1090 is greater than the level of significance is 0:05, this indicates that the variable Retained Earnings to Total Assets (RETA) berpegnaruh not significantly influence stock prices in the plantation subsector company that went public on the Indonesian stock Exchange (BEI) in the period from 2014 until 2018. Then the hypothesis H0 which states Retained Earnings to Total Assets (RETA) has no effect on stock prices of companies in the plantation subsector that listed in Indonesia stock Exchange period from 2014 until 2018.

\section{hypothesis 3}


H0: Earning Before Interest and Tax to Total Assets (EBITTA) had no effect on stock prices

Ha: Earning Before Interest and Tax to Total Assets (EBITTA) has a positive effect on stock prices

Based on table 9, test variables Earnings Before Interest and Tax to Total Assets (EBITTA) on stock prices of companies in the plantation subsector that listed in Indonesia Stock Exchange (BEI) in the period from 2014 until 2018 resulted in a probability value of 0.0000 is smaller than the level of significance ie 0:05, this indicates that the variable Earning Before Interest and Tax to Total Assets (EBITTA) has a positive effect on stock prices of companies in the plantation subsector which went public on the Indonesian stock Exchange (BEI) in the period from 2014 until 2018. Then the hypothesis Ha is received, which states that Earnings Before Interest and Tax to Total Assets (EBITTA) has a positive effect on stock prices plantation sub-sector company to go public in Indonesia stock Exchange period from 2014 until 2018.

\section{hypothesis 4}

H0: Market Value of Book Equity to Book Value of Total Liability (MVE / BTL) has no effect on stock prices

Ha: Market Value of Book Equity to Book Value of Total Liability (MVE / BTL) has a positive effect on stock prices

Based on table 9, test variables Market Value of Book Equity to Book Value of Total Liability (MVEBTL) on stock prices of companies in the plantation subsector that listed in Indonesia Stock Exchange (BEI) in the period from 2014 until 2018 resulted in a probability value of 0.0000 smaller from the level of significance is 0:05, it indicates that the variable Market Value of Book Equity to Book Value of Total Liability (MVEBTL) berpegnaruh positive on stock prices of companies in the plantation subsector that listed in Indonesia stock Exchange (BEI) in the period from 2014 until 2018. Ha accepted hypothesis which states that the Market Value of Book Equity to Book Value of Total Liability (MVEBTL) has a positive effect on stock prices plantation sub-sector company to go public in Indonesia Stock Exchange period from 2014 until 2018.

\section{WCTA influence on stock price}

Based on the results of the panel data regression WCTA variables on stock prices can be concluded no significant effect, this can be caused by many investors who invest in shortterm speculators and did not see WCTA ratio in favor of other financial ratios for consideration in the purchase of shares. this is not in accordance with the previous hypothesis statement. These results are supported by research conducted by Sukmawati et al (2014).

\section{RETA influence on stock price}

Based on the results of panel data regression of variable RETA on stock prices can be concluded no significant effect, this could be caused investors mengiginkan dividends or profits are distributed to shareholders is greater so that investors do not see the ratio of Retained Earnings to Total Assets (RETA) for a purchase consideration stock. These results are supported by research conducted Handojo (2001).

\section{EBITTA influence on stock price}


Based on the results of panel data regression of variable EBITTA on stock prices can be concluded significant positive effect, this is because some investors see this ratio to determine a company's ability to generate profits from akktiva before debt payments and taxes due if the ratio EBITTA down the net profit will potentially decrease then the resulting fall of demand for the company's stock so that the stock price may decline. These results are supported by research conducted Sukmawati et al (2014).

\section{MVEBTL influence on stock price}

Based on the results of panel data regression of variable MVEBTL on stock prices can be concluded significant positive effect, this is because investors will see this ratio to be used as one tool decision-making, because if the ratio MVEBTL down means there is an increase in total debt and this ratio describes the ability companies to meet the obligations - the obligations of the market value of equity (common shares) of course this would be one that would be a concern of investors before making an investment decision. These results are supported by research conducted Sukmawati et al (2014).

\section{REFERENCE}

[1] Kerlof, George A. (1970). The Market for 'Lemons': Quality Uncertainty and the Market Mechanism. Quarterly Journal of Economics (The MIT Press) 84 (3): 488-500.

[2] Altman, E. (1968). Financial Ratios, Discriminant Analysis and the Prediction of Corporate Bankcrupty. Journal of Finance. 589-609.

[3] Andry, Y. (2018). Arid Makin Plantation Export Performance In 2018.http://ekonomi.bisnis.com/read/20181111/12/858648/kinerja-ekspor-perkebunanmakin-gersang-pada-2018, (Accessed on July 29, 2019).

[4] E.Fama. (1970). Efficient capital markets: a review of theory and empirical work. Journal of Finance, 383-417.

[5] Fakhrurozie. (2007). "Analysis of Effect of Bankruptcy Bank With Altman Z-Score method Share Price Corporate Banking In Jakarta Stock Exchange".

[6] Handojo. (2001). "Analysis of Effect of Ratio - Financial Ratio Altman On The Stock Market". Diponegoro University of Semarang.

[7] Juanda, Bambang, and Junaidi. (2012). "Econometric Time Series Theory and Applications". Bogor: IPB Press.

[8] Jugiyanto. (2010). Portfolio Theory and Investment Analysis. Four editions. Yogyakarta: BPFE.

[9] Kamaludin. (2011). Financial Management: Basic Concepts and Implementation. Bandung: Mandar CV Maju.

[10] Marceline, AT, Yuliandhari, SW (2014). "Bankruptcy Prediction Method Using Z-Score And Its Effect On Stock Price Transportation Companies Listed in Indonesia Stock Exchange Year 2008-2012". Vol 1 No. 3. ISSN: 2355-9357.

[11] Mario. (2012). "Effects of Financial Distress Ratio Altman Model On The Stock Market In Manufacturing Companies Listed on the Stock Exchange Period 2008-2010". State University of Malang. Poor.

[12] Purwanda, E., Yuniarti, K. (2014). "Testing Impact Ratio Altman, DER, and the Interest Rate on Stock Price Company Mining Sector in Indonesia Stock Exchange". Vol XI, \# 2.

[13] Ramadan, AF, Wuryani, E. (2018). "Bankruptcy Prediction Effect On The Stock Company".

[14] Ross, SA (1977). "The Determination of the Financial Structure: The Incentive Signaling Approach", Journal of Economics, Spring, 8, pp 23-40. 
[15] Spence, Michael. (1973). Job Market Signaling. The Quartely Journal of Economics, Vol. 87, No. 3. (Aug., 1973), PP. 335-374.

[16] Sukmawati, DMN, et al. (2014). "Effect of Ratio - The ratio of the Altman Z-Score On The Stock Market (Studies in Banking Companies that go public in Indonesia Stock Exchange)". Vol 2 No. 1. 